\author{
Aleksandra Izbiańska \\ Uniwersytet Ekonomiczny we Wrocławiu \\ e-mail: aleksandra.izbianska@ue.wroc.pl \\ ORCID 0000-0001-8205-6910
}

\title{
STOSUNKI POLITYCZNO-EKONOMICZNE ROSJI Z UKRAINĄ PO 1991 ROKU
}

\section{POLITICAL AND ECONOMIC RELATIONS BETWEEN RUSSIA AND UKRAINE AFTER 1991}

DOI: $10.15611 / \mathrm{pn} .2019 .3 .03$

JEL Classification: F5, F59

Streszczenie: Na początku lat 90. XX wieku Ukraina zmagała się z wieloma problemami polityczno-ekonomicznymi związanymi z odzyskaniem niepodległości, demokratyzacją życia publicznego oraz przejściem do gospodarki wolnorynkowej. Odradzające się państwo musiało także ukształtować swoją politykę zagraniczną. Po 1991 roku Federacja Rosyjska nie zrezygnowała z prowadzenia polityki mocarstwowej, w związku z czym chciała zachować swoje wpływy na Ukrainie. Proeuropejskie aspiracje państwa ukraińskiego spotkały się z dużym niezadowoleniem strony rosyjskiej i wpłynęły na pogorszenie stosunków politycznych pomiędzy tymi państwami. Punktem przełomowym we wzajemnych relacjach była pomarańczowa rewolucja na Ukrainie, która pokazała światu, że to państwo chce przyjąć kurs proeuropejski. Celem artykułu jest pokazanie stosunków polityczno-ekonomicznych Rosji z Ukrainą po 1991 roku. Zagadnienie to zostało omówione z wykorzystaniem krytycznej analizy literatury.

Słowa kluczowe: stosunki polityczno-ekonomiczne, Rosja, Ukraina, pomarańczowa rewolucja, Majdan.

Summary: In the early 1990s, Ukraine was faced with multiple problems of political and economic nature as the country regained its independence and made a leap towards democratization of social life as well as towards free market economy. As Ukraine was created anew, it similarly had to shape its foreign politics. Following 1991, the Russian Federation did not withstand from its imperial policy, making efforts to continue to exert influence in Ukraine. Ukraine's taking of pro-European line was met with much discontent in Russia, which worsened the relations between the two countries. The Orange Revolution, through which Ukraine sent a clear message about its European aspirations, proved to be a pivotal point in their mutual relations. The aim of this article is to outline the political and economic relations between Russia and Ukraine after 1991. This issue has been discussed through a critical analysis of existing literature.

Keywords: political and economic relations, Russia, Ukraine, Orange Revolution, Majdan. 


\section{Wstęp}

Rozpad Związku Socjalistycznych Republik Radzieckich (ZSRR) sprawił, że w Europie pojawiło się kilka nowych państw. Jednocześnie dotychczasowy ład światowy został zburzony i musiano go budować na nowo. Rosja, godząc się na upadek systemu komunistycznego, nie zrezygnowała z polityki mocarstwowości. W związku z tym ze względu na swoje interesy gospodarcze dalej chciała kontrolować obszary poradzieckie, tym bardziej że coraz aktywniejsza polityka Stanów Zjednoczonych w tym regionie stanowiła duże zagrożenie dla interesów Federacji Rosyjskiej [Nowak 2011].

W relacjach Rosji z państwami powstałymi po upadku ZSRR można wyróżnić trzy charakterystyczne schematy. Kraje nadbałtyckie (Litwa, Łotwa, Estonia) od chwili uzyskania niepodległości były ukierunkowane prozachodnio, starając się o przyjęcie do Unii Europejskiej i NATO. Kraje takie jak Białoruś, Kazachstan zorientowane były na dalszą bliską współpracę z Rosją, świadomie pozostając w jej strefie wpływów. Ukraina zaś w początkowym okresie po uzyskaniu niepodległości nie miała jednoznacznie określonej polityki zagranicznej ukierunkowanej na integrację z Europą. Powiązania gospodarcze z Rosją, zwłaszcza dotyczące importu ropy i gazu, a także przemysłu ciężkiego na wschodzie (Donbas) w dużej mierze pracującego na potrzeby gospodarki rosyjskiej, nie pozwalały na radykalne działania zmierzające do integracji z zachodnią częścią Europy. Ponadto Rosja traktowała Ukrainę jako część własnej historii (Ruś Kijowska) i z punktu widzenia rosyjskiego mocarstwa niemożliwe było utracenie „kontroli” nad tym rejonem.

Wybór Władimira Putina na prezydenta Rosji, jak również zwrot ukraińskiej polityki zagranicznej, ukierunkowanej na bliską współpracę z Unią Europejską, i dążenie do integracji natychmiast zaostrzyło stosunki z Rosją, doprowadzając do zbrojnego konfliktu.

Niniejszy artykuł ma przybliżyć historię stosunków polityczno-gospodarczych Ukrainy i Rosji po 1991 r. oraz przedstawić genezę napięć, które doprowadziły do aneksji Krymu i wojny w Donbasie. W artykule zostanie również przedstawiony wpływ stosunków politycznych na wzajemne relacje gospodarcze Rosji i Ukrainy. Szczególny nacisk zostanie położony na handel surowcami energetycznymi, które są główną gałęzią we wzajemnej wymianie, a jednocześnie stanowią dominujący czynnik w rozwoju Ukrainy.

\section{Niepodległość Ukrainy}

24 sierpnia 1991 r. uchwalono Deklarację Niepodległości Ukrainy. To wydarzenie uważane jest za umowną datę odzyskania przez Ukrainę niepodległości [Hrycak 2000]. Pierwszym prezydentem wolnej Ukrainy został Leonid Krawczuk, który wraz z prezydentem Rosji - Borysem Jelcynem, oraz przewodniczącym Rady Najwyższej Białorusi - Stanisławem Szuszkiewiczem, 8 grudnia 1991 r. podpisał akt 
likwidacji ZSSR oraz powołania Wspólnoty Niepodległych Państw (WNP). Według Borysa Tarasiuka, który pełnił funkcję ministra spraw zagranicznych Ukrainy, dokument ten już wtedy pokazał proeuropejskie aspiracje Ukrainy [Mironowicz 2014].

W pierwszych latach od ogłoszenia niepodległości Ukraina zmagała się z wieloma problemami ekonomicznymi oraz politycznymi. Głównym zagrożeniem w stosunkach ukraińsko-rosyjskich była kwestia obszarów zamieszkałych w przeważającej liczbie przez potomków Rosjan - Krymu, Donbasu oraz terenów nadczarnomorskich [Mironowicz 2014]. Funkcjonowanie ówczesnej ukraińskiej gospodarki było $\mathrm{w}$ dużej mierze zależne od Rosji. Spowodowane to było ograniczonym dostępem Ukrainy do własnych zasobów energetycznych, takich jak ropa naftowa i gaz ziemny. Jednym z pierwszych poważnych kryzysów wzajemnych stosunków politycznych i ekonomicznych był konflikt gazowy z 2005 roku. Rosyjski rząd podniósł ceny gazu dla Ukrainy prawie dwukrotnie - z 50 dol. do 95 dol. za $1000 \mathrm{~m}^{3}$ [Szczęśniak 2014]. Dla gospodarki ukraińskiej był to poważny problem, ponieważ infrastruktura Ukrainy była oparta w głównej mierze na rosyjskim gazie. Podwyżkę cen udało się zahamować dzięki zaangażowaniu w mediacje ukraińsko-rosyjskiej spółki „RosUkrEnergo”, która miała prawa do eksportu gazu. Właścicielem firmy, z siedzibą w Szwajcarii, był Dmytro Firtasza, który miał powiązania handlowe z rządem zarówno w Moskwie, jak i w Kijowie.

Europa, której gospodarka była uzależniona od rosyjskiego gazu, została postawiona w bardzo trudnej sytuacji. Kryzys ukraińsko-rosyjskich relacji gospodarczych spowodował zmniejszenie dostaw gazu do Europy. W samym 2005 roku import gazu ziemnego do Austrii zmalał aż o 33\%, a na Węgry aż o 40\% [Hildenbrandt 2013]. Europę po raz pierwszy dotknęło widmo poważnego kryzysu energetycznego. Państwa europejskie stanowczo sprzeciwiały się takiemu obrotowi spraw i wydały notę o zaniepokojeniu sytuacją polityczną. Jedynym pozytywnym aspektem „I kryzysu gazowego” było uświadomienie Unii Europejskiej, że potrzebne jest poszukiwanie alternatywnych źródeł surowców energetycznych.

Pierwszy konflikt gazowy pokazał, że wymiana handlowa służyła Rosji do wywierania nacisków na suwerenne państwo i stanowiła próbę sterowania jego polityką. Podniesienie cen gazu miało skłonić Ukrainę do wstrzymania procesu integracji z Europą i pozostania w rosyjskiej strefie wpływów. Bezkompromisowe działania Rosji spotkały się ze zdecydowanym sprzeciwem większości społeczeństwa Ukrainy, co doprowadziło do fali protestów.

\section{Pomarańczowa rewolucja i drugi konflikt gazowy}

Polityka tak zwanego przyjaznego sąsiedztwa z Federacją Rosyjską ostatecznie zakończyła się wraz z wybuchem pomarańczowej rewolucji, co skutkowało dojściem do władzy Wiktora Juszczenki. Zmiana rządów i zaniechanie polityki przyjaźni sprawiły, że stosunki dyplomatyczne i gospodarcze między tymi sąsiadami znacznie się pogorszyły. Były prezydent Ukrainy, Leonid Kuczma, określał swoje poglądy 
jako proeuropejskie, jednak zawsze zależało mu na prowadzeniu polityki niekolidującej z interesami Moskwy. W momencie spadku poparcia dla władzy Kuczma w lipcu 2004 roku znacznie zmienił swoją orientację polityczną i zrezygnował z aspiracji do członkostwa w NATO oraz Unii Europejskiej. Miał nadzieję, że dzięki temu zyska przychylność prezydenta Rosji Władimira Putina, który pomoże mu utrzymać władzę na Ukrainie. Pomarańczowa rewolucja i wybór Wiktora Juszczenki na prezydenta zmieniły plany Leonida Kuczmy i rosyjskich dygnitarzy. Prozachodnie manifestacje i w pełni demokratyczne ambicje Ukrainy były ciągłym katalizatorem pogarszania się stosunków między sąsiadami.

Po zakończeniu pomarańczowej rewolucji, tj. od 2005 roku, władze Rosji opowiadały się przeciwko nowo wybranej władzy ukraińskiej. Ich działania miały przede wszystkim charakter pośredni. Ich celem było osłabienie i destabilizacja ukraińskiego rządu. Lider opozycji - Wiktor Janukowycz, otrzymywał wsparcie finansowe od Moskwy. W styczniu 2006 roku Rosja wstrzymała dostawy gazu na Ukrainę. „Działanie to miało na celu m.in. osłabienie władz ukraińskich w przededniu wyborów i wzmocnienie Partii Regionów. W okresie kampanii wyborczej media i politycy rosyjscy wspierali PR" [Szeptycki 2013].

W 2008 roku wybuchł drugi konflikt gazowy, którego przyczyną był ukraiński dług za dostawy gazu z Rosji. Wiktor Juszczenko, ówczesny prezydent Ukrainy, twierdził, że został on zapłacony przez pośrednika. Rosja temu zaprzeczyła i w rezultacie rosyjska spółka „Gazprom” przerwała dostawę gazu na Ukrainę. W odpowiedzi Ukraina podjęła decyzję o rezygnacji ze swoich obowiązków w zakresie tranzytu rosyjskiego gazu do Europy. Według niektórych źródeł zaczęto nielegalnie wypompowywać gaz z rur tranzytowych. W rezultacie Unia Europejska zaczęła obwiniać Ukrainę za spowodowanie kolejnego kryzysu energetycznego. Niektóre europejskie państwa wzywały Ukrainę do zapłaty zobowiązań i ustabilizowania sytuacji polityczno-ekonomicznej. Konflikt został załagodzony przez Międzynarodowy Fundusz Walutowy, który doradzał Ukrainie, jak rozwiązać wewnętrzny kryzys ekonomiczny. Po długich negocjacjach zdecydowano się na usunięcie pośrednika oraz rezygnację z gazu turkmeńskiego, co poskutkowało wzrostem ceny do poziomu średnio 227-228 dol. w 2009 roku, a od 2010 roku - 400 dol. [Szeptycki 2013]. Zrozumiałe jest, że taka cena nie odpowiadała stronie ukraińskiej i w 2010 roku podpisano umowę znaną jako „Charkowskie ugody”. Po jej zawarciu Ukraina otrzymała zniżkę na gaz i rezygnację z minimalnej ilości jego zakupu, a Rosja w zamian przedłużyła czas przebywania Floty Czarnomorskiej w Sewastopolu (do 2042 roku), przy jednoczesnym zwiększeniu wynagrodzenia dla Ukrainy z tego tytułu.

\section{Kwestia Floty Czarnomorskiej}

Kwestia stacjonowania Floty Czarnomorskiej (FC) odgrywała ważną rolę w stosunkach ukraińsko-rosyjskich. Po ogłoszeniu niepodległości w 1991 roku Ukraina planowała przejąć część FC, jednak wszystkie próby zakończyły się fiaskiem i wywo- 
łały sześcioletni spór z Rosją. W 1992 roku podjęto decyzję o podzieleniu Floty Czarnomorskiej pomiędzy Rosję i Ukrainę w stosunku 50:50. Ukrainie ze względu na opór oficerów FC porozumień nie udało się wcielić w życie. W 1996 roku uchwalono konstytucję Ukrainy, która zabraniała stacjonowania na terenie kraju obcych wojsk, ale w przepisach przejściowych pozwolono na stacjonowanie obcych wojsk w bazach już istniejących. Takie rozwiązanie pozwoliło Rosji na legalne stacjonowanie jej marynarki na terytorium Ukrainy. W 1997 roku podpisano międzypaństwowe porozumienie, które dotyczyło podziału Floty Czarnomorskiej pomiędzy państwami. „W zamian za potwierdzenie przez Rosję wspólnej granicy i perspektywy rozwoju współpracy gospodarczej” Ukraina zgodziła się na podział Floty Czarnomorskiej w stosunku 81,7\% (Rosja) do 18,3\% (Ukraina). Postanowienia miały obowiązywać do 2017 roku. „Niektórzy ukraińscy autorzy zauważają, że wobec braku istnienia między oboma krajami więzów sojuszniczych, obecność FC na Krymie przypomina sytuację, gdy państwo postkolonialne godzi się udostępnić bazy na swoim terytorium dawnej metropolii w zamian za korzyści materialne" [Szeptycki 2013].

Podpisanie umowy o przedłużeniu stacjonowania Floty Czarnomorskiej na Półwyspie Krymskim do 2042 roku stanęło na drodze Ukrainy do członkostwa w UE i NATO. Wymogiem koniecznym do podpisania umowy stowarzyszeniowej było zakończenie wszystkich konfliktów zbrojnych, w których zaangażowane jest państwo kandydackie. Termin „zakończenie konfliktu” jest dość szeroki i obejmuje również wycofanie się obcych wojsk z terenu państwa kandydata, jeśli inne umowy wewnętrzne NATO lub UE nie stanowią inaczej. Wiktor Janukowycz, podpisując umowę z Rosją, całkowicie przekreślił aspiracje Ukrainy o wstąpienie do NATO i UE.

\section{Przebieg konfrontacji rosyjsko-ukraińskiej}

Początek konfliktu ukraińskiego datuje się na 21 listopada 2013 roku, gdy doszło do największych zgromadzeń w Kijowie, liczących w kulminacyjnym momencie nawet 900 tysięcy ludzi. Genezy sporu należy jednak szukać w 2004 roku. Blisko dziesięć lat po „wojnie gazowej” pojawił się nowy typ konfliktu - „wojna hybrydowa”, która łączy ze sobą narzędzia militarne, ekonomiczne oraz społeczne. W dzisiejszych czasach, aby osiągnąć zamierzone cele polityczne, nie trzeba prowadzić wojny konwencjonalnej. W sytuacji, kiedy zglobalizowana światowa gospodarka wiąże siecią bardzo silnych połączeń zarówno agresora, jak i ofiarę agresji, dewastacja jednej gospodarki przez działania militarne przynosi mniej korzyści niż jej „,wrogie przejęcie" środkami ekonomicznego nacisku lub społecznego wzburzenia. Połączenie tych czynników staje się wykładnią do interpretacji konfliktu ukraińskiego, który jest preludium do nowoczesnej wojny hybrydowej. Samo zjawisko nie jest czymś nowym, ponieważ pierwsze przykłady tego typu konfliktów można odnaleźć już w latach 20. XX wieku [Sykulski 2015]. W dzisiejszych wojnach hybrydowych można wyodrębnić różne narzędzia działania. 
Tabela 1. Narzędzia wojny hybrydowej

\begin{tabular}{|c|c|c|c|c|}
\hline \multicolumn{5}{|c|}{ Narzędzia wojny hybrydowej } \\
\hline \multicolumn{3}{|c|}{ Narzędzia niemilitarne } & \multicolumn{2}{|c|}{ Narzędzia militarne } \\
\hline $\begin{array}{c}\text { środki } \\
\text { administracyjne }\end{array}$ & $\begin{array}{c}\text { środki } \\
\text { dyplomatyczne }\end{array}$ & $\begin{array}{c}\text { środki } \\
\text { ekonomiczne }\end{array}$ & $\begin{array}{c}\text { środki } \\
\text { niekonwencjonalne }\end{array}$ & $\begin{array}{c}\text { środki } \\
\text { stricte militarne }\end{array}$ \\
\hline \multirow[t]{2}{*}{$\begin{array}{l}\text { - embargo eksportowe, } \\
\text { - embargo importowe, } \\
\text { - represje } \\
\text { administracyjne } \\
\text { (wobec państw i/lub } \\
\text { obywateli), } \\
\text { - pomoc gospodarcza, } \\
\text { - tworzenie „,czarnych } \\
\text { list”, } \\
\text { - zakupy } \\
\text { zapobiegawcze }\end{array}$} & \multirow[t]{2}{*}{$\begin{array}{l}\text { wywieranie } \\
\text { nacisku } \\
\text { politycznego, } \\
\text { - bojkot, } \\
\text { propaganda }\end{array}$} & \multirow[t]{2}{*}{$\begin{array}{l}\text { - tradycyjne } \\
\text { taryfowe, } \\
\text { - tradycyjne } \\
\text { pozataryfowe, } \\
\text { - walutowo- } \\
\text { finansowe } \\
\text { (współczesne) }\end{array}$} & $\begin{array}{l}\text { - fałszowanie pieniędzy, } \\
\text { - działalność firm } \\
\text { konsultingowych, } \\
\text { - alokacja zagrożeń } \\
\text { ekologicznych, } \\
\text { - międzynarodowa } \\
\text { przestępczość } \\
\text { gospodarcza, } \\
\text { - nakręcanie spirali } \\
\text { zbrojeń, } \\
\text { - polityka zakłócania } \\
\text { stabilizacji }\end{array}$ & $\begin{array}{l}\text { - zajęcie } \\
\text { strategicznych } \\
\text { obszarów } \\
\text { przemysłowych, } \\
\text { - atakowanie floty } \\
\text { handlowej, } \\
\text { - atakowanie } \\
\text { obiektów } \\
\text { gospodarczych } \\
\text { oraz infrastruktury } \\
\text { techniczno- } \\
\text { ekonomiczno- } \\
\text { obronnej }\end{array}$ \\
\hline & & & $\begin{array}{l}\text { - wywiad gospodarczy, } \\
\text { - blokada gospodarcza, } \\
\text { - dywersja, } \\
\text { - sabotaż }\end{array}$ & \\
\hline
\end{tabular}

Źródło: opracowanie własne na podstawie [Stankiewicz 1996].

W tabeli 1 wymieniono środki wojny hybrydowej. W kontekście ukraińskim wystąpiły prawie wszystkie możliwe schematy działania, począwszy od embarg gospodarczych, przez szeroko zakrojoną propagandę, podżegania do konfliktów społecznych, kończąc na środkach stricte militarnych. Symboliczną datą wybuchu gwałtownego prorosyjskiego separatyzmu na Krymie i wschodniej Ukrainie, który rozpoczął etap uruchamiania środków militarnych, stał się 22 lutego 2014 roku. W tym samym dniu z Kijowa uciekł ówczesny prezydent Wiktor Janukowycz. Równo tysiąc kilometrów na południe w tym samym czasie w Rosji wchodziła w życie antymajdanowska rewolucja. 1 marca 2014 roku prezydent Rosji, Władimir Putin, zwrócił się z wnioskiem do Rady Federacji Rosyjskiej (izba wyższa parlamentu) o zgodę na wysłanie wojsk rosyjskich na Ukrainę. Deputowani izby wyższej Zgromadzenia Federalnego opowiedzieli się jednogłośnie (90 głosów) za użyciem siły w konflikcie z Ukrainą [Rada Federacji... 2014]. Niecały miesiąc po tych wydarzeniach tzw. zielone ludziki skutecznie doprowadziły do przyjęcia deklaracji niepodległości Republiki Krymu, destabilizacji wschodniej części Ukrainy i zachwiania światowego poczucia bezpieczeństwa. Niepodległość krymska trwała jednak krótko, bo zaledwie po siedmiu dniach od ogłoszenia niepodległości odbyło się referendum w sprawie przyłączenia Krymu do Federacji Rosyjskiej, którego frekwencja sięgała 81,36\%. W związku z tym 21 marca 2014 roku Władimir Putin sygnował dokument włączający Krym w bezpośredni obszar Federacji Rosyjskiej [Wojna na ... 2015]. 
W tym samym czasie widmo działań „separatystycznych" unosiło się nie tylko nad Donieckiem, Charkowem i Dniepropietrowskiem, ale również nad Odessą, Chersoniem i Zaporożem nad Morzem Czarnym, gdzie z powodu nagłej zmiany władzy do głosu dochodzili przeciwnicy nowych ,pomajdanowskich” władz. Już wówczas $w$ regionach tych dochodziło do rozruchów społecznych, napaści na siedziby urzędów państwowych oraz organów bezpieczeństwa. Nowy premier Ukrainy - Arsenij Jaceniuk - swoją kadencję rozpoczął od pertraktacji z wpływowymi oligarchami ukraińskimi, których nawoływał do ustabilizowania nastrojów społecznych w regionach. Rządową kartą przetargową rozmów była obietnica wpływów w nowo tworzonej administracji oraz zachowania dotychczasowych przywilejów, takich jak np. monopole. Strategia ta przyniosła wymierne korzyści - już po kilku tygodniach udało się uspokoić nastroje w większości ukraińskich miast. Praktyka ta nie sprawdziła się w Doniecku i Ługańsku, gdzie na początku kwietnia separatyści przejęli pełną władzę i rozpoczęli przygotowania do realizacji scenariusza krymskiego. W związku z niepowodzeniem polityki wpływu na wschodzie kraju 13 kwietnia 2014 roku ukraiński rząd postanowił rozpocząć „operację antyterrorystyczną" na terenach objętych silnymi nastrojami separatystycznymi, co ostatecznie przypieczętowało wybuch otwartego konfliktu z Rosją.

Tempo rozwoju kryzysu ukraińskiego, który można podzielić na trzy etapy: Euromajdan, konflikty krymski i konflikt na wschodzie Ukrainy, zaskoczyło całą światową opinię publiczną. Politycy i reporterzy z całego świata prześcigali się w analizowaniu i komentowaniu, a nawet podawaniu rozwiązań mających na celu zakończenie sporu ukraińsko-rosyjskiego. 17 marca 2014 roku Parlament Europejski nałożył sankcje na Federację Rosyjską, między innymi w postaci zamrożenia aktywów zagranicznych dla 24 najbardziej aktywnych zwolenników działań separatystycznych, ograniczenia dostępu do kapitału zagranicznego dla trzech gigantów przemysłu naftowego: Rosnieftu, Transnieftu i Gazpromu, oraz ograniczenia przekazywania i dostaw technologii podwójnego zastosowania (np. urządzenia z funkcją szyfrowania danych) [Jakie sankcje... 2014]. Warto w tym miejscu przypomnieć, iż władze polskie od samego początku (począwszy od „kryzysu krymskiego”) konsekwentnie obarczały Federację Rosyjską odpowiedzialnością za destabilizację południowej i wschodniej Ukrainy, czemu dawały wyraz także w mediach europejskich i światowych. Próbę dyplomatycznego wpłynięcia na zmianę polityki Rosji podjęto z udziałem Polski na spotkaniu w składzie Steinmeier-Sikorski-Lawrow. Nie przyniosło ono jednak realnego zbliżenia stanowisk. W sferze relacji dwustronnych, przynajmniej tych o charakterze politycznym, na linii Polska-Ukraina trwał swoisty „miesiąc miodowy”, polegający na pomocy Ukrainie w procesach demokratyzacyjnych. Warszawa bezzwłocznie uznała wyniki przyspieszonych wyborów prezydenckich na Ukrainie, w których w pierwszej turze zwyciężył Petro Poroszenko [Sikorski: Warszawa... 2014]. 


\section{Stosunki polityczno-gospodarcze Ukrainy i Rosji po 2014 roku}

Po 2014 roku stosunki gospodarcze Ukrainy z Rosją uległy pogorszeniu. Jednak już w 2017 roku, według danych pochodzących z Ukstastu, Rosja została głównym partnerem handlowym Ukrainy. Co więcej, obroty handlowe pomiędzy tymi państwami wynosiły 28\%, a obroty Ukrainy z Unią Europejską tylko 25\%. W 2017 ukraiński eksport do Rosji zwiększył się o 9,6\% w stosunku do zeszłego roku, a import aż o $39,9 \%$. Z przytoczonych danych wyraźnie wynika, że ukraińska gospodarka w coraz większym stopniu uzależnia się od Rosji. Jest to zjawisko bardzo niekorzystne, biorąc pod uwagę, że Ukraina pogłębia wymianę handlową z państwem agresorem. Według Anrijego Nowaka, szefa Komitetu Ekonomistów Ukrainy, takie działanie powoduje, że Ukraina „finansuje wojnę przeciwko samej sobie" [Rosja pozostaje... 2018]. W 2017 roku Rosja zwiększyła zakup metalowych konstrukcji dzięki odnowieniu współpracy przedsiębiorców z branży przemysłu maszynowego i metalowego. Ukraiński ekonomista Ołeksandr Ochrimenka nie wyklucza, że ,jakaś część [ukraińskich konstrukcji metalowych] została użyta na budowie krymskiego mostu". Według niego wzajemne relacje gospodarcze pomiędzy tymi krajami odnawiają się, choć kijowski rząd nie mówi o tym głośno [Rosja-Ukraina... 2018].

Niewątpliwe najważniejszym wydarzeniem z 2018 roku, które pokazuje specyfikę politycznych stosunków Rosji z Ukrainą, było podpisanie przez prezydenta Ukrainy - Petra Poroszenkę - dekretu w sprawie wygaśnięcia traktatu o przyjaźni i współpracy z Rosją [,,Niezawisimaja Gazieta” ... 2018]. W grudniu 2018 roku Rada Najwyższa przyjęła ustawę, z której wynika że od 1 kwietnia 2019 roku traktat o przyjaźni, współpracy i partnerstwie z Rosją wygaśnie.

Traktat o wzajemnej przyjaźni pomiędzy Ukrainą a Rosją podpisano w 1997 roku, a wszedł w życie 1 kwietnia 1999 roku. Obowiązywał on 10 lat, ale ze względu na brak zastrzeżeń obu stron został on automatycznie przedłużony o kolejne 10 lat. Dokument miał gwarantować nienaruszalność granic Ukrainy i Rosji oraz poszanowanie integralności terytorialnej [Parlament Ukrainy... 2018]. Według Aleksandra Guszczyna, pracownika Rosyjskiego Państwowego Uniwersytetu Humanistycznego, Poroszenko zerwał traktat dopiero w piątym roku trwania konfliktu zbrojnego, co tylko dowodzi, że cały ten zabieg miał charakter polityczny. Jego zdaniem nieodnowienie traktatu posłuży politykowi w kampanii prezydenckiej. Guszczyn nie wyklucza, że w przyszłości Ukraina może zerwać stosunki dyplomatyczne z Rosją i wprowadzić ruch wizowy [Ukraina może... 2018].

Kolejnym ważnym wydarzeniem we wzajemnych stosunkach politycznych było zamknięcie przez Ukrainę swojego przedstawicielstwa we Wspólnocie Niepodległych Państw - nastąpiło to w sierpniu 2018 roku. Instytucja WNP została powołana w 1991 roku przez Ukrainę, Białoruś i Federację Rosyjską. Ze względu na agresję ze strony Rosji od 2014 roku Kijów ograniczył swoją działalność w strukturach WNP [Koniec traktatu... 2018]. 
25 listopada 2018 roku rozpoczął się kryzys w Cieśninie Kerczeńskiej - Federalna Służba Bezpieczeństwa Rosji zaatakowała trzy ukraińskie statki: holownika Jany Kapu oraz dwa opancerzone kutry: Berdiańsk i Nikopol. Ukraińskie okręty płynęły z Oddesy do Mariupola. Strona rosyjska uważała, że ukraińskie jednostki wpłynęły na jej wody terytorialne. Według Ukrainy okręty dokonały „nieszkodliwego przepływu", co oznacza szybką i nieprzerwaną żeglugę przez morze terytorialne, które jest dozwolone przez prawo międzynarodowe [Konfrontacja w Cieśninie... 2018].

Sytuacja spowodowała kolejny kryzys międzynarodowy oraz potępienie działań Rosji ze strony państw zachodnich. Jej efektem było także to, że 26 listopada 2018 r. Ukraina wprowadziła stan wojenny, który miał obowiązywać przez 30 dni, ale jedynie na terenach bezpośrednio graniczących z Rosją, Mołdawią oraz w obwodach znajdujących się nad Morzem Czarnym i Azowskim (rys. 1).

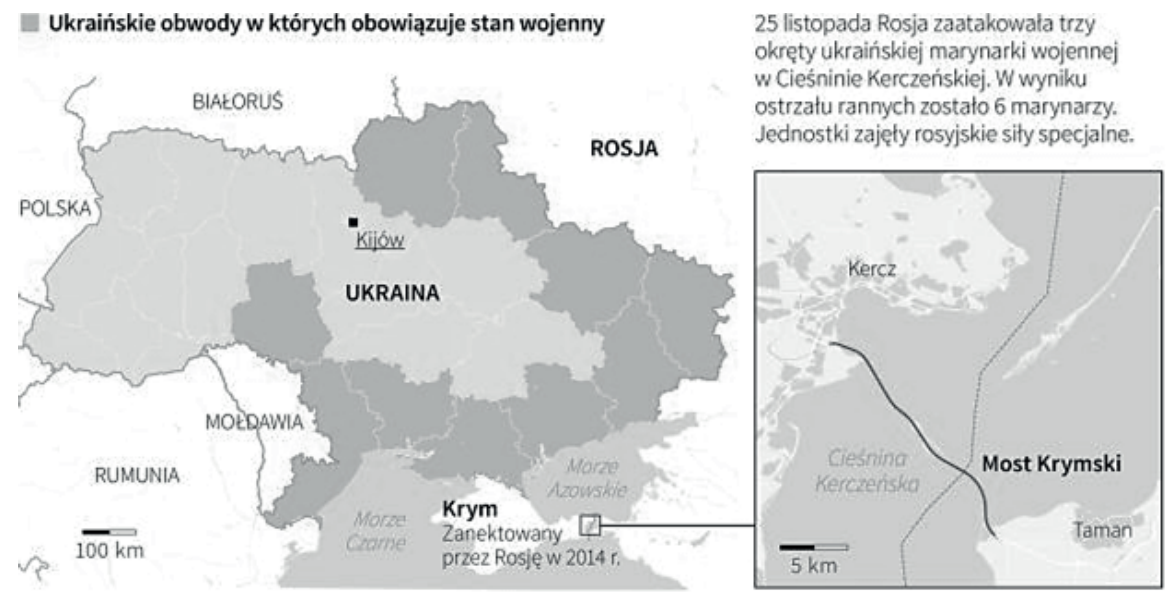

Rys. 1. Stan wojenny na Ukrainie

Źródło: https://www.tvn24.pl/raporty/konfrontacja-w-ciesninie-kerczenskiej,1320.

Polityka miękkiego blokowania ukraińskich jednostek morskich przepływających przez Morze Azowskie miała na celu ograniczenie dostępu Ukrainy do tego akwenu. Według międzynarodowych analityków agresja, która miała miejsce 25 listopada 2018 r., spowodowana była słabnącą popularnością rosyjskiego prezydenta Władimira Putina. Kreml chciał w ten sposób odwrócić uwagę Rosjan, którzy krytykowali podniesienie przez rząd wieku emerytalnego. Nie można także wykluczyć, że Rosja przez swoje zachowanie chciała zdestabilizować sytuację wewnętrzną Ukrainy, która przygotowywała się do marcowych wyborów prezydenckich.

Ukraina, zdając sobie sprawę z ograniczonego potencjału militarnego, wprowadziła stan wojenny w obwodach zagrożonych dalszą agresją oraz mobilizację sił zbrojnych. Paradoksalnie ruch Kremla, który miał osłabić popularność Petra Poroszenki, wzmocnił ją [Kryzys w Cieśninie... 2018]. 


\section{Zakończenie}

Od 1991 roku wzajemne stosunki polityczno-ekonomiczne Rosji z Ukrainą niewątpliwie można uznać za bardzo skomplikowane. Odradzające się na nowo państwo ukraińskie stało się języczkiem u wagi w Europie Wschodniej. Rosji zależało na posiadaniu wpływu na kształtowanie polityki wewnętrznej oraz zagranicznej Ukrainy. Jednak najnowsza historia pokazała, że znaczna część narodu ukraińskiego miała ambicje prozachodnie. Próba ingerencji Kremla w wybory prezydenckie w 2004 roku skończyła się pomarańczową rewolucją, którą szybko poparli zachodni politycy.

Nie ulega wątpliwości, że na przyszłość Ukrainy i jej możliwość integracji z Unią Europejską znaczny wpływ mają stosunki z Rosją. Politykę zagraniczną prowadzoną przez gabinet Władimira Putina należy jednoznacznie uznać za agresywną i prowadzoną w kierunku konfrontacji z innymi państwami. Z tego względu zakończenie konfliktu oraz poprawa stosunków pomiędzy Ukrainą i Rosją w obecnej sytuacji wydają się niemożliwe. Niestety ma to negatywny wpływ na gospodarkę Ukrainy, co utrudnia jej rozwój i ściślejszą integrację lub przystąpienie do Unii Europejskiej.

\section{Literatura}

Hildenbrandt A., 2013, Europejska energetyka - skąd poszczególne kraje czerpia energie i jak ja wykorzystuja, Pomorski Przegląd Gospodarczy, http://ppg.ibngr.pl/pomorski-przeglad-gospodarczy/ europejska-energetyka-skad-poszczegolne-kraje-czerpia-energie-i-jak-ja-wykorzystuja (dostęp 23.04.2016 r.).

Hrycak J., 2000, Historia Ukrainy 1772-1999 Narodziny nowoczesnego narodu, Instytut Europy Środkowo-Wschodniej, Lublin.

Jakie sankcje nałożono na Rosję?, https://www.polityka.pl/tygodnikpolityka/swiat/1592419,1,jakie-sankcje-nalozono-na-rosje.read (dostęp 12.09.2014 r.).

Konfrontacja w Cieśninie Kerczeńskiej, https://www.tvn24.pl/raporty/konfrontacja-w-ciesninie-kerczenskiej,1320 (dostęp 4.12.2018 r.).

Koniec traktatu o przyjaźni rosyjsko-ukraińskiej. Poroszenko podpisat dekret, https://wiadomosci. dziennik.pl/swiat/artykuly/580436,poroszenko-putin-konflikt-ukraina-rosja-traktat.html (dostęp 17.09.2018 r.).

Kryzys w Cieśninie Kerczeńskiej. O co chodzi?, https://wiadomosci.wp.pl/kryzys-w-ciesninie-kerczenskiej-o-co-chodzi-6321041249875585a (dostęp 26.11.2018 r.).

Mironowicz E., 2014, Rosja-Ukraina.25 lat między ,ograniczona wspótpraca a ograniczona konfrontacja, Wydawnictwo Naukowe Semper, Warszawa.

„Niezawisimaja Gazieta”: Kijów ostatecznie zrywa więzi z Moskwa. To może być precedens, https:// www.tvn24.pl/wiadomosci-ze-swiata,2/rosja-prasa-o-przyszlosci-stosunkow-ukrainy-irosji,889338.html (dostęp 4.12.2018 r.).

Nowak J.M., 2011, Od hegemonii do agonii Upadek Układu Warszawskiego polska perspektywa, Bellona, Warszawa. 
Parlament Ukrainy uchwalił ustawę o wygaśnięciu traktatu o przyjaźni z Rosja, https://www.bankier. pl/wiadomosc/Parlament-Ukrainy-uchwalil-ustawe-o-wygasnieciu-traktatu-o-przyjazni-zRosja-4183572.html (dostęp 6.12.2018 r.).

Rada Federacji zgodziła się na użycie rosyjskich wojsk na Ukrainie, https://www.polskieradio.pl/5/3/ Artykul/1064654, Rada-Federacji-zgodzila-sie-na-uzycie-rosyjskich-wojsk-na-Ukrainie (dostęp 1.03.2014 r.).

Rosja pozostaje głównym partnerem biznesowym Ukrainy, https://www.obserwatorfinansowy.pl/ tematyka/makroekonomia/rosja-pozostaje-glownym-partnerem-biznesowym-ukrainy/ (dostęp 30.05.2018 r.).

Rosja-Ukraina: Wojna trwa, handel się odradza, https://www.rp.pl/Konflikt-na-Ukrainie/302209913Rosja-Ukraina-Wojna-trwa-handel-sie-odradza.html (dostęp 21.02.2018 r.).

Sikorski: Warszawa brana pod uwage jako miejsce negocjacji pomiędzy Ukraina a Rosja, https://www. tvn24.pl/wiadomosci-ze-swiata,2/sikorski-warszawa-brana-pod-uwage-jako-miejsce-negocjacjipomiedzy-ukraina-a-rosja,427217.html, (dostęp 12.05.2014 r.).

Stankiewicz W., 1996, Ekonomika obrony, Wydawnictwo WSO, Wrocław.

Sykulski L., 2015, Rosyjska koncepcja wojen buntowniczych Jewgienija Messnera, Przegląd Geopolityczny, tom II.

Szczęśniak A., 2014, Petrodoalry czyli jak ropa naftowa dała początek globalnej niestabilności, nowadebata.pl/2014/11/30/petrodolary-czyli-jak-ropa-naftowa-dala-poczatek-globalnej-niestabilnosci (dostęp 30.11.2014 r.).

Szeptycki A., 2013, Ukraina wobec Rosji. Studium zależności, Wydawnictwa Uniwersytetu Warszawskiego, Warszawa.

Ukraina może nie przedlużyć traktatu z Rosja. „, Oznacza to koniec przestrzeni poradzieckiej”, http:// www.polsatnews.pl/wiadomosc/2018-12-04/ukraina-moze-nie-przedluzyc-traktatu-z-rosja-tomoze-byc-koniec-przestrzeni-poradzieckiej/ (dostęp 4.12.2018 r.).

Wojna na Ukrainie. Kiedy to się właściwie zaczęło, o co toczy się ten konflikt i czy przyjdzie do Polski?, http://natemat.pl/134003,faq-wojna-na-ukrainie-kiedy-to-sie-wlasciwie-zaczelo-o-co-toczy-sieten-konflikt-i-czy-przyjdzie-do-polski (dostęp 10.03.2015 r.). 